\title{
LDL mediated delivery of Paclitaxel and MRI imaging probes for personalized medicine applications
}

\author{
Sahar Rakhshan ${ }^{\dagger}$, Diego Alberti ${ }^{\dagger}$, Rachele Stefania, Valeria Bitonto and Simonetta Geninatti Crich ${ }^{*}$ (1)
}

\begin{abstract}
Background: The combination of imaging and therapeutic agents in the same smart nanoparticle is a promising option to perform a minimally invasive imaging guided therapy. In this study, Low density lipoproteins (LDL), one of the most attractive biodegradable and biocompatible nanoparticles, were used for the simultaneous delivery of Paclitaxel (PTX), a hydrophobic antitumour drug and an amphiphilic contrast agent, Gd-AAZTA-C17, in B16-F10 melanoma cell line. These cells overexpress LDL receptors, as assessed by flow cytometry analysis.

Results: PTX and Gd-AAZTA-C17 loaded LDLs (LDL-PTX-Gd) have been prepared, characterized and their stability was assessed under $72 \mathrm{~h}$ incubation at $37^{\circ} \mathrm{C}$ and compared to LDL loaded with Gd-AAZTA-C17 (LDL-Gd) and LDLPTX. The cytotoxic effect of LDL-PTX-Gd was evaluated by MTT assay. The anti-tumour drug loaded into LDLs showed a significantly higher toxicity on B16-F10 cells with respect to the commercially available formulation Paclitaxel kabi (PTX Kabi) used in clinical applications. Tumour cells uptake was initially assessed by ICP-MS and MRI on B16-F10 cell line. By the analysis of the image signal intensity, it was possible to extrapolate the amount of internalized PTX indirectly by the decrease of relaxation times caused by Gd, proportional to its concentration. Finally, the treatment with PTX loaded LDL on B16-F10 tumour bearing mice resulted in a marked reduction of tumour growth compared to the administration of PTX Kabi alone.
\end{abstract}

Conclusions: LDLs are selectively taken-up by tumour cells and can be successfully exploited for the selective delivery of Paclitaxel and imaging agents. For the first time the anon invasive "in vivo" determination of the amount of PTX accumulated in the tumour was possible, thanks to the use of theranostic agents of natural origin.

Keywords: Low density lipoproteins (LDL), Magnetic resonance imaging (MRI), Theranostic, Paclitaxel, Gd based contrast agents

\section{Introduction}

Nanomedicine $[1,2]$ is the branch of medicine based on the use of nano-sized carrier materials with the aim to improve the drug biodistribution. Nanomedicine aims to reduce side effects as a consequence of the more specific accumulation at the pathological site and lower

*Correspondence: simonetta.geninatti@unito.it

†Sahar Rakhshan and Diego Alberti contributed equally to this work Department of Molecular Biotechnology and Health Sciences, University

of Torino, via Nizza 52, Torino, Italy concentration in healthy tissues [3]. The nanoparticle commonly used in nanomedicine are liposomes, polymers (i.e. polylactic and glycolic polymers), micelles, and antibodies [4]. In most cases, nanocarriers have also the advantage of increase the solubility, stability and bioavailability of hydrophobic compounds in physiological conditions [5]. Moreover, nanoparticles can deliver imaging probes to perform imaging guided drug delivery $[6,7]$. Paclitaxel (PTX) has demonstrated an effective cytotoxic activity against many tumours such as ovarian cancer, breast cancer, mesothelioma, non- small cell lung cancer 


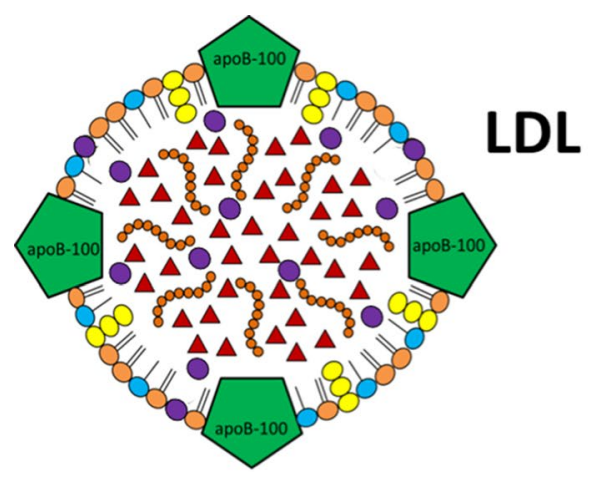

$$
\begin{aligned}
O 00 & =\text { Unesterified cholesterol } \\
\Delta & =\text { Tryglicerides } \\
& =\text { Phospholipids } \\
& =\text { Gd-AAZTA-C17 } \\
& =\text { Paclitaxel }
\end{aligned}
$$

Fig. 1 Schematic representation of LDL as a carrier for both PTX and Gd-AAZTA-C17

and melanoma [8]. The main drawback is its extremely low solubility in water $(<0.5 \mathrm{mg} / \mathrm{l})$. The commercially available formulation (Taxol) of PTX has many side effects and results neurotoxic and nephrotoxic [9]. In this contest much effort has been devoted to the development of a biodegradable carriers of natural origin capable of providing a lower and localized dose of drug to the tumour site [10]. In our previous papers, we proposed Low Density Lipoproteins (LDL) as nanoparticles of natural origin for drug and imaging agents delivery [11-13]. LDL are endogenous nanoparticles devoted to the transport of triglycerides, cholesterol, cholesterol esters within the body. Despite the use of proteins as a drug delivery platform, can be advantageous because of their good tolerability, biodegradability and low immunogenity [14-16], endogenous nanosystems have not yet received great attention in clinical practice. The main advantage of their use is the possibility of the exploitation of their natural target receptors that are upregulated in aggressive tumours such us melanoma, glioma, breast cancer [17-20]. In this study, we propose the use of LDL loaded with Paclitaxel and a lipophilic MRI contrast agent (Gd-AAZTA-C17) to target selectively B16-F10 melanoma cells (Fig. 1). These tumour cells overexpress LDL receptors (LDLR) as demonstrated by a cytofluorimetric assay. The synthesis and characterization of the LDL adduct was described together with cytotoxicity tests (MTT). Finally, the biocompatibility and treatment of solid melanoma tumours obtained by the subcutaneous injection of B16 was assessed and compared with the effect of Paclitaxel kabi (PTX-Kabi, Fresenius Kabi), the water suspended drug formulation used in clinical studies.

\section{Materials and methods}

Gd-AAZTA-C17 [21] (AAZTA-C17=6-bis(carboxymeth yl)amino-4-carboxymethyl-6-heptadecyl-1,4-diazepan1 -yl]acetic acid, Fig. 2) was purchased by Cage Chemicals Srl (Novara, Italy).

\section{Preparation of LDL-Gd, LDL-PTX and LDL-PTX-Gd adducts}

LDL loaded with PTX (LDL-PTX) nanoparticles were prepared by adding dropwise $40 \mu \mathrm{l}$ of PTX dissolved in DMSO $(53 \mathrm{mM})$ to a stirred suspension of LDL in PBS $(2.15 \mathrm{ml})$. After $4 \mathrm{~h}$ incubation at $37^{\circ} \mathrm{C}$, the non-encapsulated drug was removed by dialysis (MW cut off 14 KDa) against PBS (Phosphate-Buffered Saline, $\mathrm{pH}$ 7.4, $1.5 \mathrm{~L}$ ) at $4{ }^{\circ} \mathrm{C}$ for $16 \mathrm{~h}$. The LDL loaded with Gd-AAZTAC17 complexes (LDL-Gd) was prepared as described in a previous paper [22]. Briefly, LDL loaded with GdAAZTA-C17 complexes (LDL-Gd) and LDL loaded with both Gd-AAZTA-C17 and PTX (LDL-PTX-Gd) were prepared by adding dropwise $3.8 \mathrm{ml}$ of Gd-AAZTAC17 dissolved in PBS $(0.09 \mathrm{mM}$, below critical micellar concentration) to a stirred suspension of LDL or LDL-PTX $(0.6 \mu \mathrm{M}, 2 \mathrm{ml})$ at $37^{\circ} \mathrm{C}$ for $2 \mathrm{~h}$. The unbound complex was eliminated by dialysis as described before. Finally, the LDL adducts were concentrated using Vivaspin centrifuge filters (molecular weight cut-off 50,000, Sartorius) to be used for in vitro and in vivo studies.

\section{Protein concentration determination}

The amount of LDL protein was measured using the colorimetric commercially available Bradford Protein Assay (Biorad). Firstly, a calibration curve was made using a Bovine Serum Albumin (BSA) standard solution. The

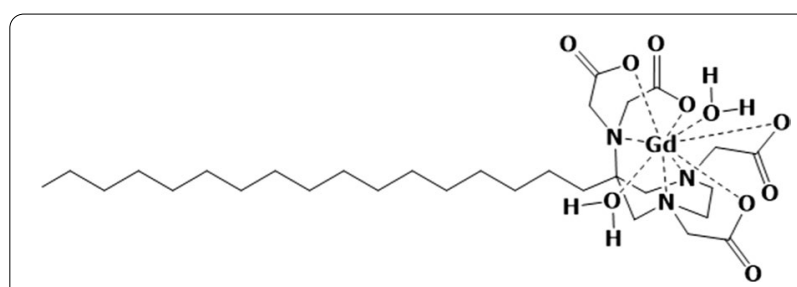

Fig. 2 Schematic representation of the Gd based contrast agent Gd-AAZTA- C17 
absorbance was measured at $595 \mathrm{~nm}$ using a JenWay 6715 UV/VIS spectrophotometer (Essex, UK).

\section{Relaxometric measurements}

The water proton longitudinal relaxation rates $(\mathrm{R} 1=1 /$ $\mathrm{T}_{1}$ ) of LDL-Gd and LDL-PTX-Gd solutions were measured with a Spinmaster relaxometer (Stelar S.r.l., Mede, Italy) at $21.5 \mathrm{MHz}$ and $25^{\circ} \mathrm{C}$. To measure the amount of Gd loaded in the LDLs, a glass vial containing $100 \mu \mathrm{l}$ of $\mathrm{HCl} 37 \%$ and $100 \mu \mathrm{l}$ of sample solution was placed in an oven at $110{ }^{\circ} \mathrm{C}$ for $16 \mathrm{~h}$. Upon this treatment, all Gd is dissolved as the free aquo-ion. The $\mathrm{Gd}^{3+}$ concentration was determined using a calibration curve obtained using standard $\mathrm{GdCl}_{3}$ solutions $(0.01-2 \mathrm{mM})$. The method was double-checked by ICP-MS element-2 (Thermo-Finnigan, Rodano, Italy).

\section{HPLC determination of Paclitaxel content in nanoparticles}

In order to determine the encapsulation efficiency of Paclitaxel in LDL, $100 \mu \mathrm{L}$ aliquot of LDL-PTX or LDLPTX-Gd was mixed with $300 \mu \mathrm{L}$ of acetonitrile. The sample was then filtered by Phree Phospholipid Removal $1 \mathrm{ml}$ tube (Phenomenex, Torrance, CA, USA) and analysed by Waters Alliance 2695 HPLC system with Waters 2998 Photodiode Array (PDA) Detector, using a SunFire C18 Column, $100 \AA$, $3.5 \mu \mathrm{m}, 4.6 \mathrm{~mm} \times 150 \mathrm{~mm}$ and $0.1 \%$ TFA in water (solvent $\mathrm{A}$ ) and $0.1 \%$ TFA in acetonitrile (solvent B). Elution was carried out with a linear $40 \%$ to $100 \%$ gradient of solvent B into A over $23 \mathrm{~min}$ at a $1 \mathrm{ml}$ $/ \mathrm{min}$ flow rate and a retention time of $10.8 \mathrm{~min}$. The detection wavelength was set at $227 \mathrm{~nm}$. Sample solution was injected at a volume of $25 \mu \mathrm{l}$. The HPLC was calibrated with standard solutions of 0.5 to $17 \mu \mathrm{g} / \mathrm{ml}$ of PTX dissolved in acetonitrile (correlation coefficient of $R^{2}=0.9992$ ). The encapsulation efficiency was defined by the ratio of measured and initial amount of PTX encapsulated in nanoparticles.

\section{Determination of nanoparticles size}

The LDL-Gd, LDL-PTX-Gd and LDL-PTX adducts hydrodynamic mean diameter was determined using a Malvern dynamic light-scattering spectrophotometer (Malvern Instruments, Malvern, UK). All samples were analyzed at $25^{\circ} \mathrm{C}$ in filtered (cut-off $=0.2 \mu \mathrm{m}$ ) PBS buffer (pH 7.4).

\section{In vitro PTX and Gd-AAZTA-C17 release}

To perform stability tests, LDL-PTX and LDL-PTX-Gd nanoparticles were dispersed in $2 \mathrm{ml}$ of PBS at a $0.6 \mu \mathrm{M}$ $\mathrm{LDL}$ and placed in a dialysis bag $(\mathrm{MWCO}=14 \mathrm{kD})$. The samples underwent dialysis against $1 \mathrm{~L}$ of $\mathrm{PBS}$ at $37{ }^{\circ} \mathrm{C}$ with slight agitation via mechanical stirring. At various time intervals $(24,48,72 \mathrm{~h}), 200 \mu \mathrm{l}$ of sample was collected for measurement of size, protein, PTX and Gd concentration, as described before, by RP-HPLC and relaxometry, respectively. The stability of nanoparticles for PTX and Gd concentration were calculated as percentage difference measured with respect to $t=0$ set at $100 \%$.

\section{Cell lines}

Mouse melanoma (B16-F10) cell line was obtained from the American Type Culture Corporation (ATCC) and they were cultured in DMEM (Lonza) supplemented with $4.5 \mathrm{~g} / \mathrm{l}$ glucose, $4 \mathrm{mM}$ glutamine and 10\% FBS (Lonza). The medium contained $100 \mathrm{U} / \mathrm{ml}$ penicillin and $100 \mathrm{U} /$ $\mathrm{ml}$ streptomycin. Cell line was maintained in a humidified incubator at $37^{\circ} \mathrm{C}, 5 \% \mathrm{CO}_{2}$.

\section{FACS analysis of $L D L$ receptor expression}

In order to perform FACS (Fluorescence Activated Cell Sorting) analysis, $3 \times 10^{5}$ B16-F10 cells were seeded in $6 \mathrm{~cm}$ dishes. After $24 \mathrm{~h}$ incubation in $37^{\circ} \mathrm{C}$, the cells were incubated for $24 \mathrm{~h}$ with their culture media supplemented with 10\% LPDS (Lipoprotein Deficient Serum, Biomedical Technologies Inc., Stoughton, MA). Finally, the cells were washed with PBS, detached with trypsin/ EDTA, transferred in $15 \mathrm{ml}$ falcon tubes and counted in PBS. Cell number was determined using a cell sorting chamber (Burker-Turk chamber). B16-10 cells were divided in 3 falcon tubes containing $1 \times 10^{6}$ cells. [Sample 1: no antibody incubated (control); sample 2: secondary antibody incubated; sample 3: primary and secondary antibodies incubated]. All cells were fixed with $4 \%$ paraformaldehyde ( $7 \mathrm{~min}, 1 \mathrm{ml}$ ); then $2 \mathrm{ml}$ of PBS were added to the cells before centrifugation (1100 rpm for $5 \mathrm{~min}$ ). After a further washing with $3 \mathrm{ml}$ of PBS, cells were permeabilized with $0.1 \%(\mathrm{v} / \mathrm{v})$ of Tween 20 in PBS $(20 \mathrm{~min}$, $1 \mathrm{ml}$ ); then $2 \mathrm{ml}$ of PBS were added to the cells and they were centrifuged (1100 $\mathrm{rpm}$ for $5 \mathrm{~min}$ ); the PBS was removed, and the cells were further washed with $3 \mathrm{ml}$ of PBS and centrifuged (1100 rpm for $5 \mathrm{~min}$ ). All the cells were then incubated at $4{ }^{\circ} \mathrm{C}$ in $10 \%$ FBS (v/v) in PBS (10 min, $1 \mathrm{ml}$ ) to block nonspecific protein protein interaction. Then $2 \mathrm{ml}$ of PBS were added to the cells and they were centrifuged (1100 rpm for $5 \mathrm{~min}$ ); after a further washing with $3 \mathrm{ml}$ of PBS the primary antiLDL receptor monoclonal antibody (Abcam ab52818) was incubated $30 \mathrm{~min}$ at $4{ }^{\circ} \mathrm{C}$ to cell samples $\mathrm{n}^{\circ} 3(3 \mu \mathrm{L}$ in $200 \mu \mathrm{l}$ of $0.1 \%$ BSA/PBS). Then $3 \mathrm{ml}$ of PBS were added to the cells and they were centrifuged ( $1100 \mathrm{rpm}$ for $5 \mathrm{~min}$ ); the PBS was removed, and the cells were further washed with $3 \mathrm{ml}$ of 
PBS and centrifuged (1100 rpm for $5 \mathrm{~min}$ ). Then, a swine antirabbit secondary antibody FITC-conjugated (Dako F0205) (3 $\mu \mathrm{l}$ in $200 \mu \mathrm{l}$ of $0.1 \%$ BSA/PBS) was incubated to samples 2 and 3 . The incubation was performed at $4{ }^{\circ} \mathrm{C}$ for 30'. All samples were washed with PBS (3 ml) and centrifuged (1100 rpm for $5 \mathrm{~min}$ ). Finally, all the cells were diluted in PBS $(250 \mu \mathrm{L})$ and evaluated for their FITC fluorescence on a flow cytometer (Becton Dickinson, FACS Calibur).

\section{MTT assay}

$2.5 \times 10^{3} \mathrm{~B} 16-\mathrm{F} 10$ cells/well were incubated in a 96-well microtiter plate at $37{ }^{\circ} \mathrm{C}$ and $5 \% \mathrm{CO}_{2}$ atmosphere in their normal medium and after $24 \mathrm{~h}$ incubation the medium was changed with medium containing 10\% LPDS. $24 \mathrm{~h}$ later, the medium was replaced with a fresh medium containing LDL-PTX adducts, PTX-kabi (Fresenius-Kabi) or LDL-PTX-Gd adducts $(0.1-10 \mu \mathrm{M}$ PTX) and incubated for $24 \mathrm{~h}$ at $37{ }^{\circ} \mathrm{C}$ and $5 \% \mathrm{CO}_{2}$. After this time, the incubation medium was eliminated and $0.45 \mathrm{mg} / \mathrm{ml}$ of MTT labeling reagent (Sigma) dissolved in medium was added into each well and the plates were incubated for $4 \mathrm{~h}$ at $37^{\circ} \mathrm{C}$ and $5 \% \mathrm{CO}_{2}$ [19]. Then, after removing the medium containing MTT reagent, $150 \mu \mathrm{L}$ of the solubilization solution (DMSO) were added into each well to solubilize the formazan salt crystals produced by the metabolism of live cells and the microplate was incubated $30 \mathrm{~min}$ at room temperature. Finally, absorbance was read at $570 \mathrm{~nm}$ with IMark microplate reader (Biorad). Cell vitality was reported as percentage of cell vitality observed in treated samples relative to that observed in control cells. The experiment was performed in triplicate and the data were graphically presented as mean $\pm \mathrm{SD}$.

\section{Uptake experiments}

For the in vitro uptake experiments, $2 \times 10^{5} \mathrm{~B} 16$-F10 cells were seeded in $6 \mathrm{~cm}$ diameter dishes. The day after, the cells were incubated for $24 \mathrm{~h}$ with the respective culture media supplemented with 10\% LPDS to increase LDLR expression. Finally, the cells were incubated for $24 \mathrm{~h}$ with Gd loaded LDL particles (LDL-Gd) at 20 and $50 \mu \mathrm{g} / \mathrm{ml}$ LDL concentration and PTX-Gd-AAZTA loaded LDL particles at 10, 20 and $30 \mu \mathrm{g} / \mathrm{ml} \mathrm{LDL}$. At the end of the incubation, cells were washed three times with $10 \mathrm{ml}$ icecold PBS and detached with trypsin/EDTA. Cells were also transferred into glass capillaries for MRI analysis (see below). After MRI analysis, the samples were resuspended in $0.2 \mathrm{ml}$ PBS and sonicated in ice for 30 " at $30 \%$ power. The amount of proteins, proportional to the number of cells of each cell sample lysate, was evaluated by the Bradford assay (see above). Gd content of B16-F10 was determined using inductively coupled plasma mass spectrometry (ICP-MS). Sample digestion was performed with $0.2 \mathrm{ml}$ of concentrated $\mathrm{HNO}_{3}(70 \%)$ added in $0.2 \mathrm{ml}$ of sample lysate using a high performance Microwave Digestion System (ETHOS UP Milestone, Bergamo, Italy). After digestion, the volume of each sample was brought to $3 \mathrm{ml}$ with ultrapure water and the sample was analyzed by ICP-MS.

\section{Evaluation of LDL-PTX-Gd particles uptake in vitro and in vivo by magnetic resonance imaging (MRI)}

MR images were acquired on a Bruker Avance Neo $300 \mathrm{MHz}$ spectrometer (7 T) equipped with a Micro 2.5 microimaging probe (Bruker BioSpin, Ettlingen, Germany). In vitro glass capillaries containing B16-F10 cells were placed in an agar phantom and MR imaging was performed using a standard $\mathrm{T}_{1}$-weighted multislice spin- echo sequence (TR/TE/NEX $=250 / 5.04 / 6$, $\mathrm{FOV}=1.2 \mathrm{~cm}) . \mathrm{T}_{1}$ relaxation times were calculated using a standard Saturation Recovery Spin Echo.

In vivo adult male C57BL/6J mice were maintained under specific pathogen-free conditions at the animal facility of the Department of Molecular Biotechnology and Health Sciences (University of Turin, Italy). All animal experiments have been carried out in accordance with the EU Directive 2010/63/EU for animal experiments. The animal treatment protocol was approved by the Italian Ministry of Health (Authorization Number 1012/2015-PR). B16-F10 cells were cultured as described above and tumours were generated by the injection of $0.5 \times 10^{6}$ B16-F10 cells in a final volume of $0.15 \mathrm{ml}$ PBS subcutaneously in the neck of the mouse. Seven days after the B16-F10-cell injection mice developed solid tumours of approximately $42 \pm 26 \mathrm{~mm}^{3}$ in volume, Tumour bearing mice $(\mathrm{n}=3)$ received (iv) a bolus of LDLPTX-Gd at a dose of $35 \mu \mathrm{mol} / \mathrm{kg} \mathrm{Gd}$. $\mathrm{T}_{1}$-weighted spinecho MR-images (TR/TE/NEX $=200: 4: 8, F O V=3 \mathrm{~cm}$ ) were acquired in pre-anesthetized mice by injecting tiletamine/zolazepam (Zoletil 100; Virbac, Milan, Italy) $20 \mathrm{mg} / \mathrm{kg}$ + xylazine (Rompun; Bayer, Milan, Italy) $5 \mathrm{mg} /$ $\mathrm{kg}$ before and 6 , and $24 \mathrm{~h}$ after the particles injection. The mean signal intensity (SI) enhancement (\%) in the regions of interest (ROI) manually drawn on the whole tumour, and on the muscle, kidneys, spleen and liver, at the different time intervals was calculated accordingly to the following equation (Eq. 1) and the mean measured SI was normalized using a tube containing standard Gd solution:

$$
\begin{aligned}
\mathrm{SI} \% \text { Enhancement }= & ((\text { mean SIPOST }- \text { mean SIPRE }) / \\
& \text { mean SIPRE }) \times 100
\end{aligned}
$$

The concentration of the Gd complex in the tumour and different tissues and organs was calculated from Eq. 2: 


$$
\frac{S I_{P R E}}{S I_{P O S T}}=\frac{\left\{\left[1-\exp (-T R-T E) R 1_{P R E}\right]\right\} \exp (-T E x R 2)}{\left\{\left[1-\exp (-T R-T E) R 1_{P O S T}\right]\right\} \exp (-T E x R 2)}
$$

In Eq. 2 [23], TR is the repetition time, TE is the echo time, and $R_{1}$ and $R_{2}$ are the water proton relaxation rates.

The $R_{1}$ precontrast (R1(pre)) maps were obtained by using a SNAP sequence; R1 postcontrast (R1(post)) maps were calculated by using the pre- and postcontrast SI ratio (Eq. 2) calculated in the regions of interest, which were manually drawn on $\mathrm{T}_{1}$-weighted images; $\mathrm{r} 1 \mathrm{p}$ (in cell) is the intracellular relaxivity of LDL-PTX-Gd $\left(6.14 \mathrm{mM}^{-1} \mathrm{~s}^{-1}\right.$ at $\left.7 \mathrm{~T}\right)$ and it was used to calculate the intra-tumour Gd concentration.

In vivo tumour growth assessment and histological studies upon LDL-PTX or PTX kabi treatment in administered mice When mice developed solid tumours of $42 \pm 26 \mathrm{~mm}^{3}$, they received an intravenous injection of LDL-PTX $(\mathrm{n}=5)$ or PTX Kabi $(\mathrm{n}=7)$ (corresponding to a concentration of $4 \mathrm{mg} / \mathrm{kg}$ PTX). Treated mice were compared to untreated control mice $(n=8)$. Mice were treated for five days consecutively once a day and the tumour growth were monitored with MRI at $1 \mathrm{~T}$ on an Aspect M2-High Performance MRI System (Aspect Magnet Technologies Ltd., Netanya, Israel) every 2 days. The $\mathrm{T}_{2}$-weighted $\mathrm{MR}$ images were acquired at $1 \mathrm{~T}$ with an Aspect M2-High Performance MRI System (Aspect Magnet Technologies Ltd., Netanya, Israel) consisting of a NdFeB magnet, equipped with a $35 \mathrm{~mm}$ solenoid $\mathrm{Tx} / \mathrm{Tr}$ coil of inner diameter $35 \mathrm{~mm}$. This system is equipped with fast gradient coils (gradient strength, $450 \mathrm{mT} \mathrm{m}-1$ at $60 \mathrm{~A}$ : ramp time, $250 \mu \mathrm{s}$ at $160 \mathrm{~V}$ ) with a field homogeneity of $0.2-0.5$ gauss. The MR images were performed by using a $\mathrm{T}_{2}$-weighted protocol (TR/ $\mathrm{TE} / \mathrm{NEX}=2500: 50: 6 ; \mathrm{FOV}=4.0 \mathrm{~cm}$ ). Animals were anesthetized before MRI examination by injecting tiletamine/zolazepam (20 mg/kg; Zoletil 100, Virbac, Milan, Italy) and xylazine (5 mg/kg; Rompun, Bayer, Milan, Italy). The tumour volume $\left(\mathrm{mm}^{3}\right)$ was calculated in the region of interest (ROI) manually drawn on the whole tumour by ITK-SNAP software. Tumour volume enhancement (\%) was calculated according to the Eq. 3 where time $=0$ indicates the day of the first treatment and time $=\mathrm{n}$ indicates the days when mice were acquired by MRI. At the end of the experiment, mice were sacrificed and untreated tumour (control) or tumour treated with LDL-PTX or PTX-Kabi were explanted, fixed in $4 \%$ paraformaldehyde for $16 \mathrm{~h}$ and then were embedded in paraffin. Dewaxed 5 um sections were stained with hematoxylin-eosin. Images of tumour tissue were acquired using an optical microscope (Olympus BX41).

\section{Results \\ Preparation of LDL-Gd, LDL-PTX and LDL-PTX-Gd}

The preparation of LDL-PTX and LDL-PTX-Gd nanoparticles was performed using the procedure described in materials and methods. The recovery of LDL (recovery $=\%$ of the protein remaining in the solution after the loading process), the PTX encapsulation efficiency and the adduct sizes, measured by dynamic light scattering (DLS) are reported in Table 1. The size of all the LDL adducts were similar to native LDL $(23 \pm 1 \mathrm{~nm})$ thus indicating that the loading process does not change dramatically the protein tridimensional structure. The LDL recovery when PTX and Gd-AAZTA-C17 were encapsulated alone was $>44 \%$. When LDL-PTX adducts were loaded with Gd-AAZTA-C17, both the LDL recovery and the encapsulation efficiencies decreased. In this formulation, the quantification of PTX by RP-HPLC measurements showed lower drug incorporation corresponding to a number of Paclitaxel molecules per LDL of $97 \pm 17$, maybe due to replacements effects. The size of LDL-PTXGd adduct measured by DLS was $34 \pm 6 \mathrm{~nm}$ (Additional file 1: Figure S1), The millimolar relaxivity of LDL-PTXGd adduct $\left(\mathrm{r}_{1 \mathrm{p}}\right.$; the observed relaxation rate of a water solution containing $1 \mathrm{mM}$ of a paramagnetic species) was $25 \pm 4.4 \mathrm{mM}^{-1} \mathrm{~s}^{-1}\left(21.5 \mathrm{MHz}, 25^{\circ} \mathrm{C}\right), 30 \%$ lower than the $\mathrm{r}_{1 \mathrm{p}}$ found for LDL-Gd.

\section{Stability of LDL-PTX and LDL-PTX-Gd adducts}

The in vitro release profile of Gd in LDL-PTX-Gd and PTX in LDL-PTX and LDL-PTX-Gd was investigated by

$$
((\text { tumour volume }(\text { time }=\mathrm{n})-\text { tumour volume }(\text { time }=0) / \text { tumour volume }(\text { time }=0)) \times 100
$$

\begin{tabular}{|c|c|c|c|c|c|c|c|}
\hline NPs & $\begin{array}{l}\text { LDL\% recovery } \\
\pm S D\end{array}$ & $\begin{array}{l}\text { PTX\% recovery } \\
\pm \text { SD }\end{array}$ & $\begin{array}{l}\text { Gd\% recovery } \\
\pm \mathrm{SD}\end{array}$ & $\begin{array}{l}\text { LDL/PTX } \\
\text { Molar ratio } \\
\pm \text { SD }\end{array}$ & $\begin{array}{l}\text { Size } \\
\mathrm{nm} \\
\pm \mathrm{SD}\end{array}$ & $\begin{array}{l}\text { LDL/Gd } \\
\text { Molar ratio } \\
\pm \text { SD }\end{array}$ & $\begin{array}{l}\text { Relaxivity } \\
\mathrm{mM}^{-1} \mathrm{~s}^{-1} \\
\pm \mathrm{SD}\end{array}$ \\
\hline LDL-PTX & $44 \pm 5$ & $12 \pm 2$ & - & $1: 262 \pm 29$ & $26.5 \pm 4$ & & \\
\hline LDL-Gd & $62 \pm 11$ & - & $63 \pm 5$ & - & $22.8 \pm 2.5$ & $1: 284 \pm 24$ & $31 \pm 4.7$ \\
\hline LDL-PTX-Gd & $24 \pm 11$ & $4 \pm 1$ & 22 & $1: 97 \pm 17$ & $34 \pm 6$ & $1: 186 \pm 7$ & $25 \pm 4.4$ \\
\hline
\end{tabular}

Table 1 Characterization of LDL-PTX, LDL-Gd and LDL-PTX-Gd nanoparticles 


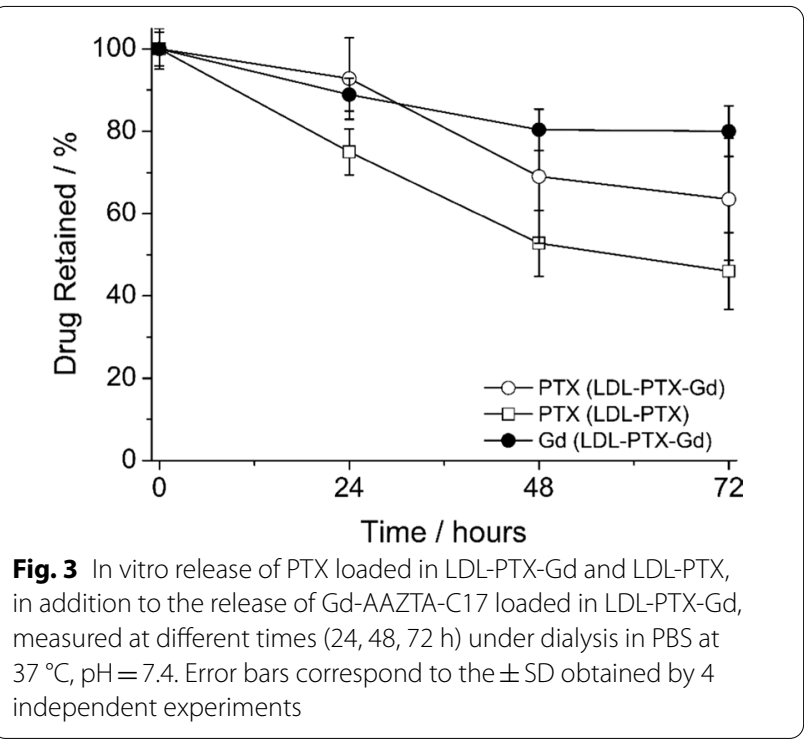

RP-HPLC measurements of samples dialyzed at $37{ }^{\circ} \mathrm{C}$ in PBS for 24, 48, $72 \mathrm{~h}$. The cumulative percentage release is shown in Fig. 3. PTX release in the LDL-PTX was higher (almost 55\%, in $72 \mathrm{~h}$ ) than in LDL-PTX-Gd (35\%, $72 \mathrm{~h}$ ). Gd-AAZTA-C17 showed higher stability in the LDL adduct (20\% release in $72 \mathrm{~h}$ ). This high stability of PTX in LDL-PTX-Gd (>90\% after $24 \mathrm{~h}$ at $37{ }^{\circ} \mathrm{C}$ ) allows to perform uptake studies in B16-F10 cells. We can surmise that the lower PTX release observed in the LDL adduct containing both PTX and Gd-AAZTA-C17 is due to the exchange of the more unstable PTX molecules located on the external protein surface by Gd-AAZTA-C17 due to its higher affinity for the same binding sites present on the protein surface. In fact, due to its high hydrophobicity, it was hypothesized that PTX is in part located in the internal core and in part in the external surface of the protein.

\section{Evaluation of low-density lipoproteins receptors (LDLRs) expression on melanoma cell lines}

The LDLRs expression by B16-F10 murine melanoma cell line was evaluated by Flow cytometry (FACS) analysis. Cells were incubated 30' with a monoclonal antibody (mAb) specific for LDLRs and then with the FITClabeled secondary $\mathrm{Ab}$ (FITC = fluorescein isothiocyanate) (Fig. 4). Untreated cell samples (violet area) were used as control. The specific binding of the secondary Ab was determined incubating cells avoiding pre-incubation with the primary $\mathrm{Ab}$ (green line). AntiLDL receptors $\mathrm{mAb}$ yielded a high positive signal in B16-F10 cells thus demonstrating a high level of expression of LDLRs (pink line).

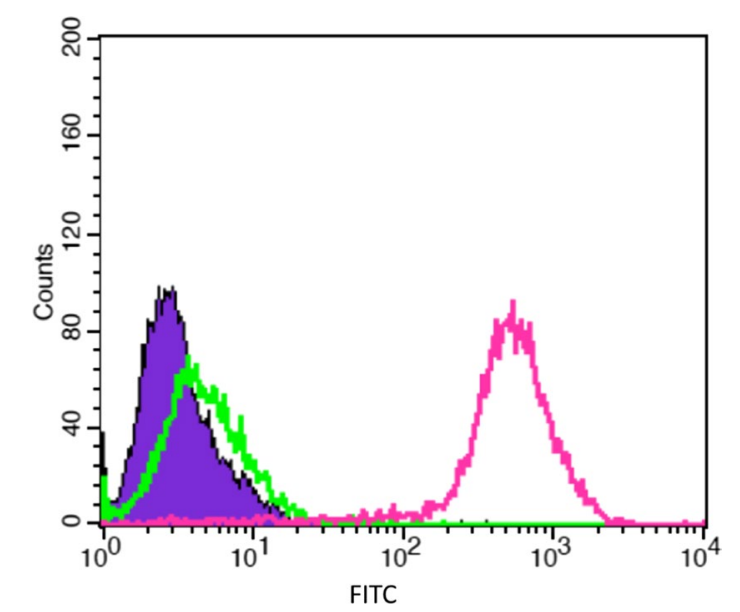

Fig. 4 FACS analysis of the LDL receptors expression on B16-F10 cell lines. Representative panel shows the fluorescence intensity of LDL receptors expression on B16-F10 cell line. The positivity is defined as fluorescence intensity of FITC (antiLDL receptor Ab conjugated with FITC secondary Ab) (pink line) higher than that of the FITC secondary Ab used as control (green line). Untreated cells are shown in violet

\section{Toxicity Test of PTX-LDL adducts}

Vitality assays were performed on B16-F10 by using the MTT assay. The MTT assay is a colorimetric assay for measuring cell metabolic activity. Cells were incubated for $24 \mathrm{~h}$ in the presence of LDL-PTX, LDL-PTX-Gd, LDL-Gd and a commercially available Paclitaxel formulation administered to human patients (Paclitaxel Kabi) at increasing concentrations (Fig. 5). The range of concentrations of PTX corresponds to plasma levels of the drug achievable in human treatments [13]. Figure 5A shows that in B16-F10 melanoma cells the cytotoxic effect is significantly higher when PTX is administered to cells loaded into LDL with respect to PTX-kabi formulation. The addition of Gd- AAZTA-C17 to the PTX-LDL adduct did not change the cytotoxic effect of the delivered drug (Fig. 5B). As expected LDL-Gd that do not contain PTX did not show any toxicity (Fig. 5C).

\section{Cellular uptake of LDL-Gd and LDL-PTX-Gd in B16-F10 cells} As established above, B16-F10 express a relatively high concentration of LDL receptors on their cytoplasmatic membrane, able to internalize LDL. Cells were incubated in the presence of LDL-Gd and LDL-PTX-Gd at different concentration for $24 \mathrm{~h}$ at $37{ }^{\circ} \mathrm{C}$ and $5 \% \mathrm{CO}_{2}$. Cells were then washed with cold PBS, collected and the amount of internalized Gd was measured by ICP-MS. The amount of $\mathrm{Gd}$ is taken as a reporter of the extent of cell internalized LDL nanoparticles. In order to compare different experiments, the amount of internalized Gd was normalized to the total protein cell content. The values of internalized Gd were higher for B16-F10 incubated in 

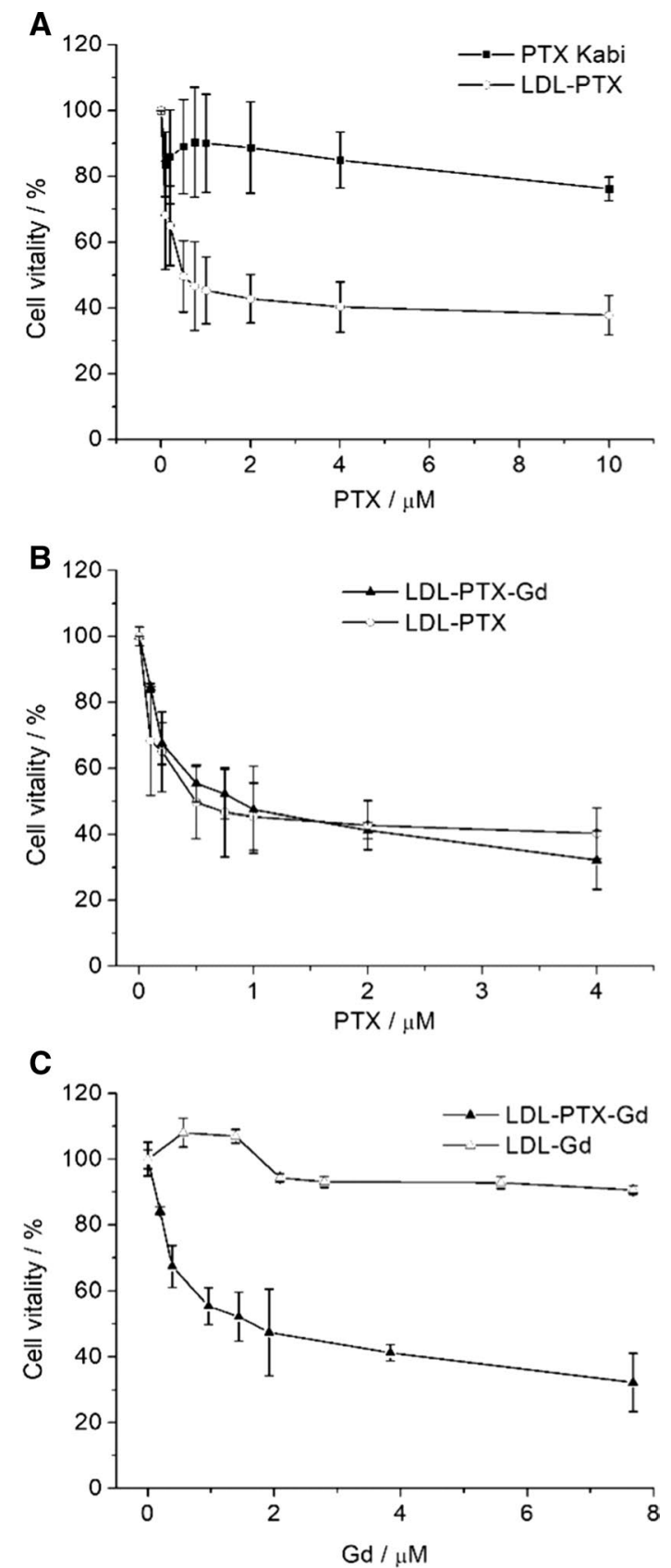

Fig. 5 Percentage of vitality (measured by MTT assay) of B16-F10 measured after $24 \mathrm{~h}$ of incubation at different concentrations of Paclitaxel Kabi and LDL-PTX (A), LDL-PTX-Gd and LDL-PTX (B), and LDL-Gd (C). Graphs show the mean \pm SD of \% vitality evaluated on 3 independent experiments

the presence of LDL-Gd than incubation of LDL-PTXGd (Fig. 6) accordingly to the higher Gd content in the adduct that do not contain PTX and to the toxic effect of the internalized drug that can alter cellular metabolism. The higher uptake of LDL-Gd was observed both
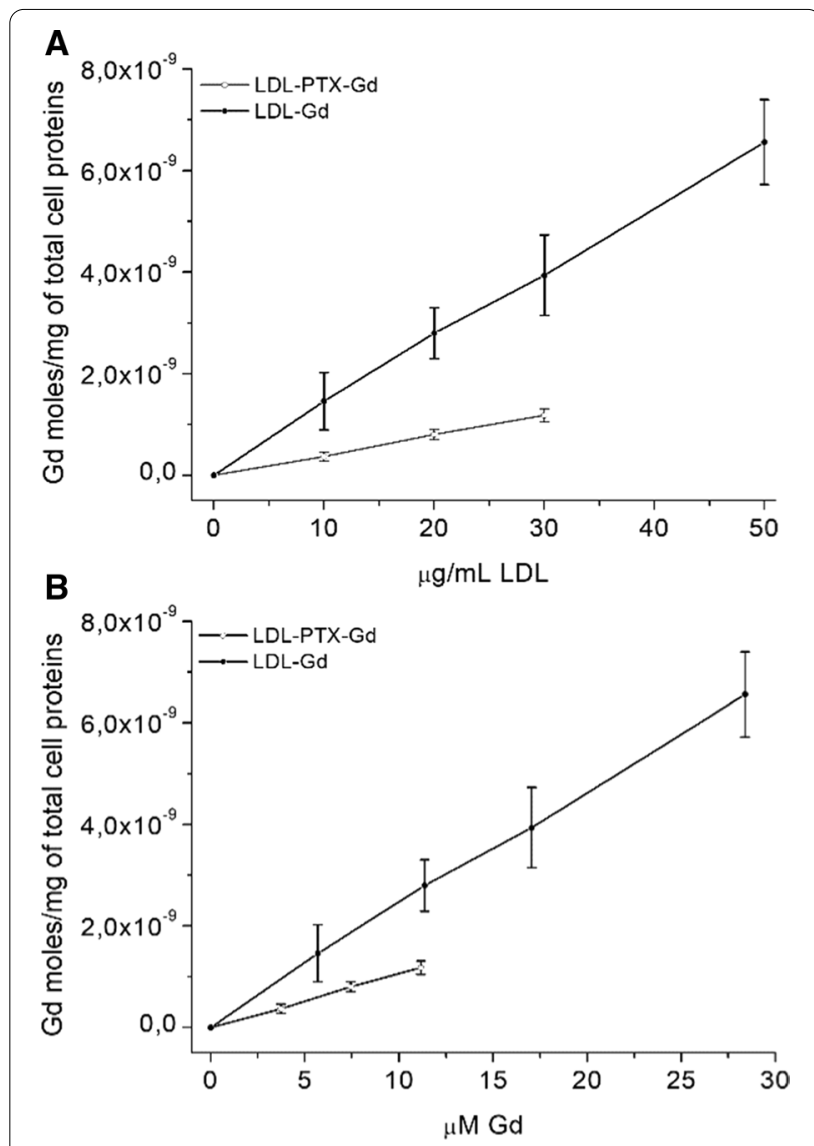

Fig. 6 Uptake of Gd in B16-F10 cells incubated in the presence of increasing concentration of LDL-Gd (black circle) and LDL-PTX-Gd (white circle) for $24 \mathrm{~h}$ at $37^{\circ} \mathrm{C}$. Gd moles/mg of total proteins are reported $\mathbf{A}$ vs LDL concentration $(\mu \mathrm{g} / \mathrm{ml})$ or $\mathbf{B}$ vs Gd concentration $(\mu \mathrm{M})$; Error bars indicate the SD evaluated on three independent experiments

when the Gd internalized is plotted as a function of LDL (Fig. 6A) concentration and of Gd concentration (Fig. 6B).

\section{Magnetic resonance imaging (MRI)}

In order to assess whether the amount of LDL-Gd and LDL-PTX-Gd taken up by B16-F10 cells can generate a well detectable MRI contrast, $\mathrm{T}_{1}$ - weighted images were acquired at $7 \mathrm{~T}$ on glass capillaries filled with B16-F10 cell pellets. Figure 7 shows the well detectable signal intensity (SI) enhancement of cells incubated in the presence of LDL-Gd or LDL-PTX-Gd at different concentrations in comparison with untreated control cells.

Being known the PTX/Gd ratio present in the LDL adduct, the amount of PTX taken-up by B16-F10 can be easily indirectly obtained by measuring the relaxation rates of cell pellets. In fact, the relaxation rates $\left(R_{1}\right)$ measured on cells pellets (Fig. 7B) are directly proportional 

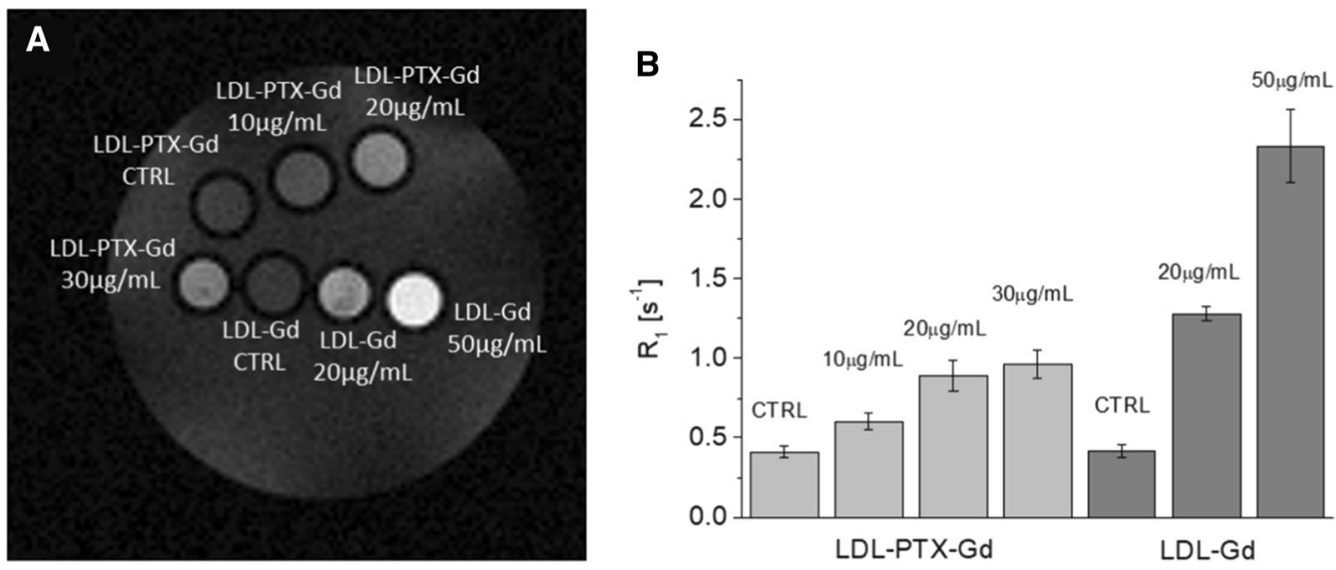

Fig. 7 A $T_{1}$-weighted spin-echo MR image of an agar phantom with glass capillaries containing untreated B16 control cells and cells incubated with 10,20 and $30 \mu \mathrm{g} / \mathrm{ml}$ of LDL-PTX-Gd and with 20 and $50 \mu \mathrm{g} / \mathrm{ml}$ of LDL-Gd for $24 \mathrm{~h}$ at $37^{\circ} \mathrm{C}$; all the concentrations are referred to the $\mu \mathrm{g} / \mathrm{ml}$ of protein ( $L D L)$ incubated $\mathbf{B}$ the corresponding relaxation rates $\left(R_{1}\right)$ measured on cell pellets for unlabeled control B16 cells (CTRL) and cells incubated with 10, 20 and $30 \mu \mathrm{g} / \mathrm{ml} \mathrm{LDL-PTX-Gd}$ and 20 and $50 \mu \mathrm{g} / \mathrm{ml}$ of LDL-Gd; $R_{1}$ values are reported in Additional file 1: Table S1. Error bars indicates \pm SD

Table 2 Calculation of internalized PTX in B16-F10 cell line

\begin{tabular}{lclll}
\hline $\begin{array}{l}\text { [LDL] } \\
\text { incubated } \\
\text { with B16- }\end{array}$ & $\begin{array}{l}\text { nmol PTX } \\
\text { incubated }\end{array}$ & $\begin{array}{l}\text { nmol PTX } \\
\text { internalized }\end{array}$ & $\begin{array}{l}\text { nmol/mI PTX } \\
\text { internalized }\end{array}$ & $\begin{array}{l}\% \\
\text { internalized }\end{array}$ \\
\hline $10 \mu \mathrm{g} / \mathrm{ml}$ & 3.88 & 0.078 & 16.56 & 2.0 \\
$20 \mu \mathrm{g} / \mathrm{ml}$ & 7.76 & 0.24 & 40.7 & 3.1 \\
$30 \mu \mathrm{g} / \mathrm{ml}$ & 11.6 & 0.30 & 47.8 & 2.6 \\
\hline
\end{tabular}

to the product of the Gd concentration and its millimolar relaxivity at $7 \mathrm{~T}\left(\mathrm{r}_{1 \mathrm{p} \text { (in cell) }}=6.14 \mathrm{mM}^{-1} \mathrm{~s}^{-1}\right)(\mathrm{Eq} .4)$. Using the measurement of $R_{1}$ enhancement of cell pellets it was possible to calculate the amount of Paclitaxel theoretically taken-up by B16-F10 (Eq. 5). The results are reported in Table 2.

$$
\mathrm{R}_{1 \text { post }}=[\mathrm{Gd}] \mathrm{mM} \times \mathrm{r}_{1 \mathrm{p}(\text { in cell })}+\mathrm{R}_{1 \mathrm{~d}(\text { cell })}
$$

where $R_{1 d(\text { cell) }}$ and $R_{1 \text { post }}$ are the relaxation rates measured on cell pellets before and after the incubation with LDL-PTX-Gd.

Being the $[\mathrm{Gd}] /[\mathrm{PTX}]$ ratio $=1.9$ (Table 1$)$ and $\mathrm{R}_{1 \mathrm{~d}(\text { cell })}$ the relaxation rate measured on untreated control cells.

$$
[P T X]=\frac{R_{1(\text { post } G d)}-R_{1 d(\text { cell })}}{1.9 * r 1 p}
$$

\section{In vivo diagnostic and therapeutic study}

The in vivo study was carried out on a syngeneic mouse model obtained by subcutaneous implantation, of B16-F10 cells. The tumour bearing mice were prepared by injecting ca. 0.5 million B16-F10 cells subcutaneously at the bottom of the neck of C57BL/6J mice ( $n=6)$. After 7 days, the B16F10 tumours reached a volume of approximately $42 \pm 26$ $\mathrm{mm}^{3}$. In order to evaluate the biodistribution of PTX, and in particular the amount of drug that LDL can deliver to the tumours, mice $(n=3)$ intravenously received a bolus of LDL-PTX-Gd $35 \mu \mathrm{mol} / \mathrm{kg}$ and $15.7 \mathrm{mg} / \mathrm{Kg}$ as expressed in term of Gd and PTX, respectively. $\mathrm{T}_{1}$-weighted multi slice spin-echo MR images were acquired before, 6 and $24 \mathrm{~h}$ after contrast administration (Fig. 8).

As expected, high \% SI enhancement (Table 3) is observed in the tumour region and in the liver due to the high LDLRs expression on both tumour cells and normal hepatocytes. The amount of PTX present in muscle, liver and in the melanoma tissue (Table 4) was calculated from the SI enhancement using the equations described in material and methods. Interestingly, the amount of PTX found in tumours at $6 \mathrm{~h}$ is similar to the PTX internalized by B16-F10 cells in vitro after $10 \mu \mathrm{g} / \mathrm{ml}$ incubation of LDL (LDL-PTX-Gd).

On this basis, due to the high uptake of PTX in the liver and in order to avoid a liver acute toxicity, we decided to divide the total dose in 5 different treatments, once a day for 5 consecutive days as reported in many recently published protocols [24, 25]. To perform the treatment study, a total number of 20 mice were injected with 0.5 million B16-F10 cells as described above. The mice were then rando $\mathrm{ml} y$ divided into three groups. The first group $(n=5)$ received the LDL-PTX, the second group $(\mathrm{n}=7)$ was treated with PTX-Kabi, and the third $(\mathrm{n}=8)$, as control, was treated with equal volume of PBS. Each mouse received in the tail vein a dose of LDL-PTX and PTX-Kabi corresponding to $4 \mathrm{mg} / \mathrm{kg}$ PTX once per day for 5 consecutive days. Mice were monitored three times 


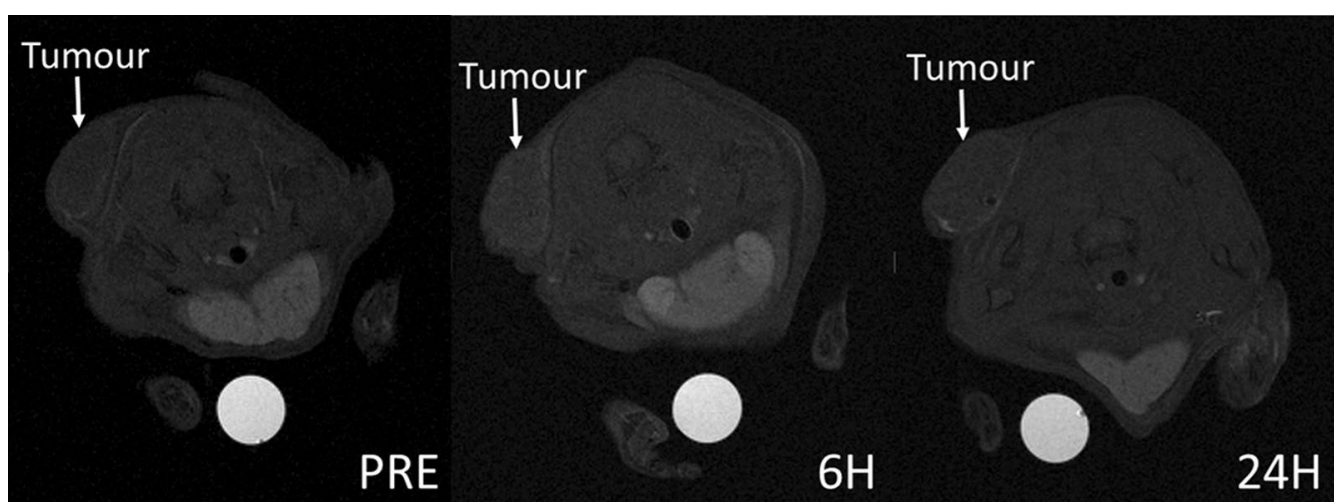

Fig. $8 T_{1}$-weighted spin-echo MR images (7T) acquired before (PRE), 6 and $24 \mathrm{~h}$ after contrast administration

Table 3 SI \% enhancement measured on different organs 6 and $24 \mathrm{~h}$ after LDL-PTX-Gd administration

\begin{tabular}{lcc}
\hline Tissue & $\begin{array}{l}\mathbf{6} \mathbf{h}(\mathbf{S I} \% \\
\text { enhancement }) \pm \mathbf{S D}\end{array}$ & $\begin{array}{l}\mathbf{2 4} \mathbf{h}(\mathbf{S I} \% \\
\text { enhancement }) \pm \mathbf{S D}\end{array}$ \\
\hline Tumour & $23.3 \pm 1.0$ & $2.9 \pm 11.5$ \\
Muscle & $12.8 \pm 5.3$ & $1.2 \pm 4.7$ \\
Liver & $151.2 \pm 36.7$ & $27.9 \pm 24.2$ \\
Spleen & $39.7 \pm 13.0$ & $15.1 \pm 7.6$ \\
Kidneys & $15.3 \pm 9.4$ & $-3.6 \pm 1.9$ \\
\hline
\end{tabular}

Table 4 Amount of in vivo PTX internalized after LDL-PTX-Gd administration

\begin{tabular}{lcl}
\hline Tissue & $\mathbf{6} \mathbf{h}$ PTX $\mathbf{n m o l} / \mathbf{g} \pm \mathbf{S D}$ & $\begin{array}{l}\mathbf{2 4} \mathbf{h} \text { PTX } \\
\mathbf{n m o l} / \mathbf{g} \pm \mathbf{S D}\end{array}$ \\
\hline Tumour & $15.0 \pm 0.70$ & $1.85 \pm 7.4$ \\
Muscle & $7.5 \pm 2.5$ & $0.04 \pm 2.5$ \\
Liver & $558 \pm 38$ & $65 \pm 38$ \\
\hline
\end{tabular}

weekly for body weight and for evidence of tumour or PTX treatment-associated morbidity till the end of the experiment (Additional file 1: Figure S2).

Figure 9A and Additional file 1: Figure S3 show that the tumour size of mice treated with LDL-PTX monitored by MRI (at $1 \mathrm{~T}$ ) was significantly lower than that of mice treated with PTX-Kabi or PBS. Interestingly, the high variability observed on the PTX-Kabi group was significantly reduced using the personalized delivering with LDL-PTX. At the end point, mice were euthanized and tumours were excised and undergone to ex vivo histological analysis. Image J analysis of ROIs manually drawn on the whole excised tumour image $H \& E$ stained, showed that the percentage of necrotic area with respect

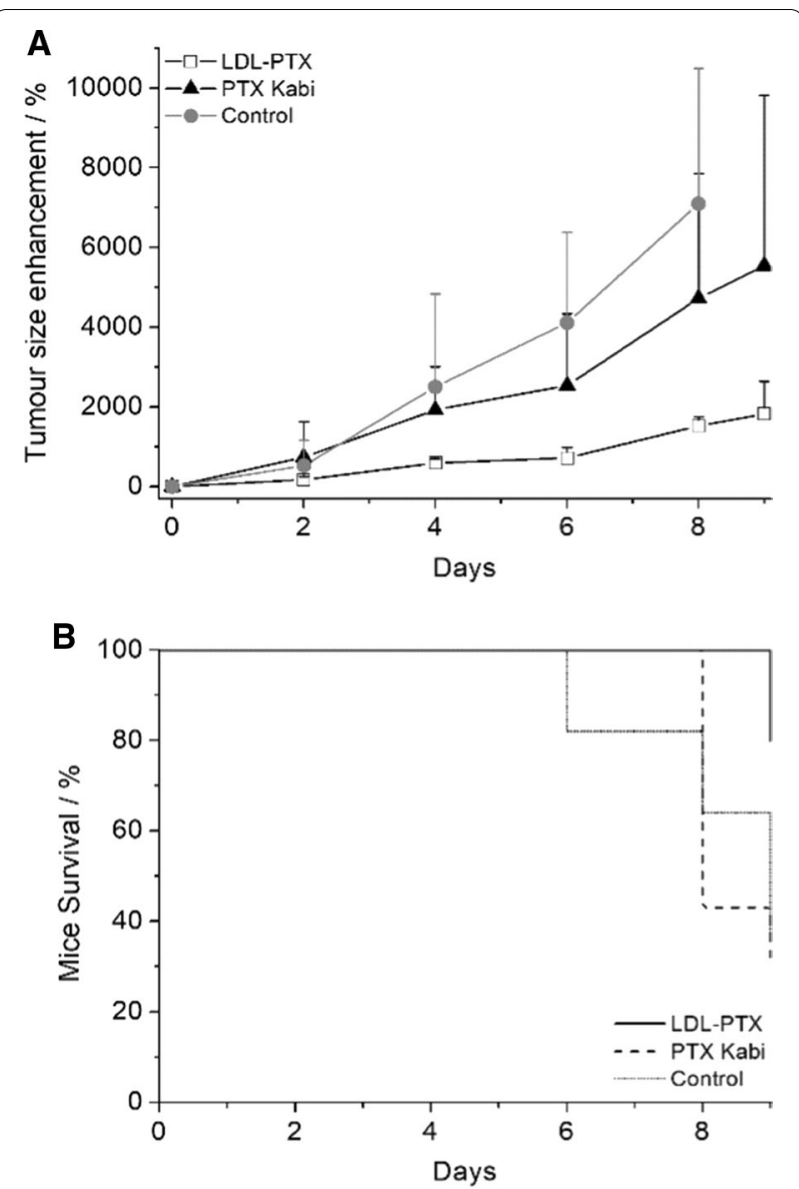

Fig. 9 A Tumour-growth evaluation performed after LDL-PTX or PTX Kabi treatment. The graph shows the \% of tumour size enhancement measured by MRI on untreated control mice, LDL-PTX or PTX Kabi treated mice. Error bars indicate the SD. At day 2, 4, and 6, P-values were $0.19,0.022,0.05$, respectively. B Mice survival curve performed on untreated control mice, LDL-PTX or PTX Kabi treated mice 
to the total tumour area was ca. $15,30,40 \%$ respectively for untreated control tumours, PTX Kabi and LDL-PTX. Figure 10 displays a representative magnification of the necrotic areas in the differently treated tumours.

\section{Discussion}

The general aim of this work is to establish a new theranostic (therapeutic and diagnostic) approach based on the use of LDL for the simultaneous delivery of both antitumour drug and imaging agents. Herein developed system was tested on melanoma cells (B16-F10) that is a well known, extremely aggressive and metastatic tumour [26]. The development of procedures that lead to the accumulation of drugs at the targeting site is an important task for personalized medicine applications [27]. In this paper LDLs were exploited to deliver simultaneously different compounds inside the pathological cells, for developing an efficient antitumour theranostic nano-system. The crucial objective for MRI, as it is less sensitive with respect to other imaging modalities, is to use highly sensitive contrast agents compatible with the resulting thermodynamic stability $[28,29]$. Furthermore, the pharmacological activity of a drug can be largely improved by an intracellular drug delivery. Among the different classes of Gd-based MRI contrast agents, Gd-AAZTA [30, 31] has been selected because of its high sensitivity due to the coordination of two water molecules in fast exchange with the bulk. The Gd-complex is functionalized with an aliphatic carbon chain to pursue the binding to LDL in order to allow a selective delivery to tumour cells overexpressing LDLRs. The relaxivity observed after binding with LDL, due to the increase of the tumbling time of the macromolecular adduct, is high (ca $30 \mathrm{mM}^{-1} \mathrm{~s}^{-1}$ at $20 \mathrm{MHz}$ ) and is able to generate a good contrast enhancement when internalized in tumour cells overexpressing LDL receptors as murine melanoma (B16-F10) cell line. Paclitaxel, the antitumour drug selected for the treatment is highly hydrophobic with an extremely low solubility in water. For these reasons we propose LDL, the proteins devoted to lipids transport, as a selective carrier of natural origin. The herein developed LDL-PTX-Gd has the aim of delivering a precise therapy that can be followed in real time by in vivo imaging. In fact, Fig. 9 shows that the antiproliferative action of PTX in vivo is more effective and more reproducible in the mouse group as a consequence of its specific intracellular delivery through LDLRs. The obtained results appear very promising as they may potentially provide patients affected by melanoma with an improved therapeutic option based on the LDL driven delivery. In fact, the results reported in this article demonstrates an improved cytotoxic effect in B16-F10 tumours cells compared to commercial Paclitaxel Kabi administered alone (Fig. 5A) both in in vitro and in vivo. This interesting observation demonstrated
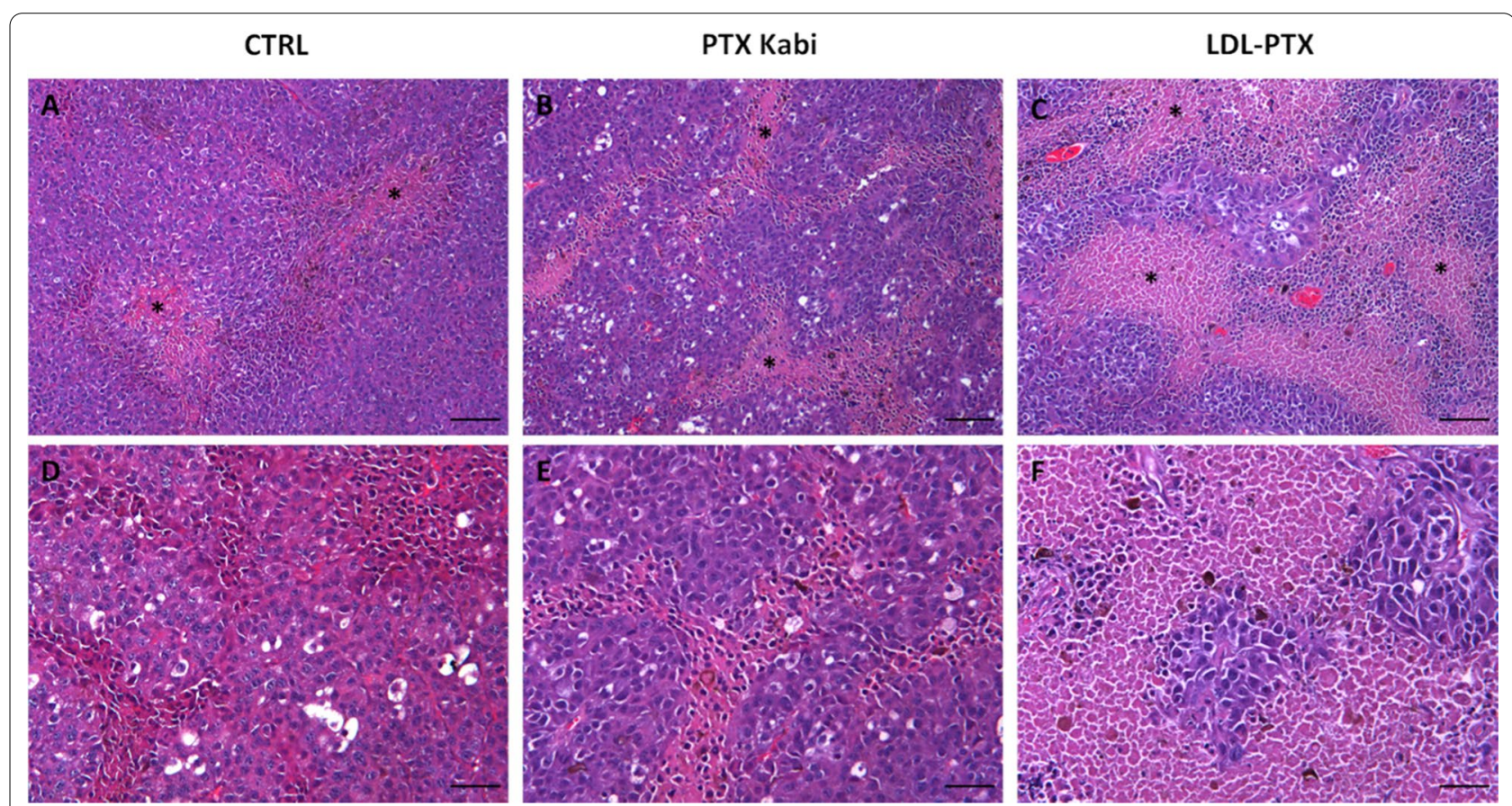

Fig. 10 Representative H\&E images of excised B16-F10 untreated control tumours (A, D), or treated with PTX Kabi (B, E) or LDL-PTX (C, F) nanoparticles. A-C Asterisks indicate necrotic tissue. A, B, C Scale Bars $=100 \mu \mathrm{m}$, Magnification $\times 100 ; \mathbf{D}, \mathbf{E}, \mathbf{F}$ Scale Bars = $50 \mu \mathrm{m}$, Magnification $\times 200$ 
the specific accumulation of PTX loaded LDL driven by LDL receptors. Furthermore, Fig. $5 \mathrm{~B}$ shows that the toxicity of PTX in form of LDL-PTX but also within the LDL-PTX-Gd is the same, demonstrating the absence of toxicity due to $\mathrm{Gd}$ by itself. This is an important point, due to the recent alerts caused by the observation of tiny amounts of $\mathrm{Gd}$ may retained in the tissues of patients injected with Gd based contrast agents [32, 33]. These observations bring a growing concern about the fate of the Gd ion after the injection in the patient, despite serious consequences have been observed only for patients with impaired renal function, Furthermore, herein it has been demonstrated that by measuring the relaxation rate or simply the signal intensity enhancement of the corresponding MRI image, it is possible to extrapolate the PTX distribution in real time in a noninvasive and repeatable protocol. This potentially allows to the oncologist to have information needed to obtain an early detection of therapeutic outcome. The cytotoxicity of the LDL-PTX adduct was tested in vivo together with the evaluation of drug distribution. The specific delivery of the PTX loaded LDL in B16-F10 tumour bearing mice improved the specific delivery of PTX with respect to PTX Kabi thus markedly reducing the tumour growth. The cytotoxic effect was confirmed by histological studies on excised tumour tissues.

\section{Conclusions}

In this study the adduct formed by loading of LDL with Gd-AAZTA-C17 and Paclitaxel was prepared and characterized for the first time to our knowledge. This therapeutic and at the same time diagnostic approach appears to have a great potential in providing highly specialized, more potent and safer tools to treat cancer. The use of endogenous biomolecules is a successful strategy for achieving this goal. Indeed, these molecules are ideal for the development of drug- delivery platforms, thanks to their biocompatibility and biodegradability. Thanks to the high uptake of LDL-PTX-Gd in in vitro and in vivo in melanoma cells we observed a significant therapeutic improvement with the advantage of monitoring the coloaded Gd complex by MRI.

\section{Supplementary Information}

The online version contains supplementary material available at https://doi. org/10.1186/s12951-021-00955-9.

Additional file 1: Figure S1. Size distribution by number, performed by DLS. Size of Native LDL (A), Size of LDL in LDL-Gd (B), in LDL-PTX (C) and in LDL-PTX-Gd (D). Figure S2. \% Mice weight enhancement performed after LDL-PTX or PTX Kabi treatment or on untreated control mice. Error bars indicate the SD. Figure S3. Representative $\mathrm{T}_{\mathbf{2}}$ weighted images (1 T) control, PTX Kabi and LDL-PTX treated mice, monitored by MRI (7T) on day 0 and 4 . Table S1. $R_{1}$ values measured on cell pellets of Fig. 7.

\section{Acknowledgements}

This work was performed in the framework of the Consorzio Interuniversitario di Ricerca in Chimica dei Metalli dei Sistemi Biologici (CIRCMSB)

\section{Authors' contributions}

SR and RS contributed to the preparation purification and characterization of LDL adducts and to the animal treatment and MRI study; DA performed cell study and animal treatment; BV performed histological study; SGC and DA conceived the idea, wrote and revised the manuscript. All authors read and approved the final manuscript.

\section{Funding}

The research leading to these results has received funding from AIRC under IG 2019, ID 23267 project (PI Geninatti Crich Simonetta) and from the Italian Ministry for Education and Research (MIUR) for yearly FOE funding to the EuroBiolmaging Multi-Modal Molecular Imaging Italian Node (MMMI).

Availability of data and materials

Not applicable.

\section{Declarations}

Ethics approval and consent to participate Not applicable.

\section{Consent for publication}

The corresponding author of this manuscript, Simonetta Geninatti Crich, on behalf of all co-authors (Sahar Rakhshan, Diego Alberti, Rachele Stefania, Valeria Bitonto) declares the consent of publication of this manuscript in the Journal of Nanobiotechnology. All authors have read and approved the submitted final version.

\section{Competing interests}

None of the authors has any conflicts of interest.

Received: 30 April 2021 Accepted: 3 July 2021

Published online: 13 July 2021

\section{References}

1. Wilhelm J, Wang Z, Sumer BD, Gao J. Exploiting nanoscale cooperativity for precision medicine. Adv Drug Deliv Rev. 2020;158:63-72.

2. Dasgupta A, Biancacci I, Kiessling F, Lammers T. Imaging-assisted anticancer nanotherapy. Theranostics. 2020;10:956.

3. Mitchell MJ, Billingsley MM, Haley RM, Wechsler ME, Peppas NA, Langer R. Engineering precision nanoparticles for drug delivery. Nat Rev Drug Discov. 2020;4:1-24.

4. Blanco E, Shen H, Ferrari M. Principal of nanoparticle design for overcoming biological barriers to drug delivery. Nat Biotechnol. 2015;33:941.

5. Alberti D, Protti N, Franck M, Stefania R, Bortolussi S, Altieri S, Deagostino A, Aime S, Geninatti CS. Theranostic nanoparticles loaded with imaging probes and rubrocurcumin for combined cancer therapy by folate receptor targeting. ChemMedChem. 2017;12:502-9.

6. Rezvantalab S, Drude NI, Moraveji MK, Güvener N, Koons EK, Shi Y, Lammers T, Kiessling F. PLGA-based nanoparticles in cancer treatment. Front Pharmacol. 2018:9:1260.

7. Geninatti Crich S, Terreno E, Aime S. Nano-sized and other improved reporters for magnetic resonance imaging of angiogenesis. Adv Drug Deliv Rev. 2017;119:61-72.

8. Wang F, Porter M, Konstantopoulos A, Zhang P, Cui H. Preclinical development of drug delivery systems for paclitaxel-based cancer chemotherapy. J Control Release. 2017;267:100-18.

9. Singla AK, Garg A, Aggarwal D. Paclitaxel and its formulations. Int J Pharm. 2002;235:179-92.

10. Ma P, Mumper RJ. Paclitaxel nano-delivery systems: a comprehensive review. J Nanomed Nanotechnol. 2013;4:1000164.

11. Geninatti Crich S, Alberti D, Szabo I, Deagostino A, Toppino A, Barge A, Ballarini F, Bortolussi S, Bruschi P, Protti N, Stella S. MRI-guided neutron capture therapy by use of a dual gadolinium/boron agent targeted at 
tumour cells through upregulated low-density lipoprotein transporters. Chem A Eur J. 2011;17:8479-86.

12. Alberti D, Deagostino A, Toppino A, Protti N, Bortolussi S, Altieri S, Aime $\mathrm{S}$, Geninatti CS. An innovative therapeutic approach for malignant mesothelioma treatment based on the use of $\mathrm{Gd} /$ boron multimodal probes for MRI guided BNCT. J Control Release. 2018;280:31-8.

13. Alberti D, Protti N, Toppino A, Deagostino A, Lanzardo S, Bortolussi S, Altieri S, Voena C, Chiarle R, Geninatti Crich S, Aime S. A theranostic approach based on the use of a dual boron/Gd agent to improve the efficacy of Boron Neutron Capture Therapy in the lung cancer treatment. Nanomed Nanotechnol Biol Med. 2015;11:741-50.

14. Conti L, Lanzardo S, Ruiu R, Cadenazzi M, Cavallo F, Aime S, Geninatti CS L-Ferritin targets breast cancer stem cells and delivers therapeutic and imaging agents. Oncotarget. 2016;7:66713.

15. Iqbal $H$, Yang $T$, Li T, Zhang M, Ke H, Ding D, Deng $Y$, Chen $H$. Serum protein-based nanoparticles for cancer diagnosis and treatment. J Control Release. 2020;329:997-1022.

16. Mishra S, Sharma S, Javed MN, Pottoo FH, Barkat MA, Alam MS, Amir M, Sarafroz M. Bioinspired nanocomposites: applications in disease diagnosis and treatment. Pharm Nanotechnol. 2019:7:206-19.

17. Thaxton CS, Rink JS, Naha PC, Cormode DP. Lipoproteins and lipoprotein mimetics for imaging and drug delivery. Adv Drug Deliv Rev. 2016;106:116-31.

18. Di L, Maiseyeu A. Low-density lipoprotein nanomedicines: mechanisms of targeting, biology, and theranostic potential. Drug Deliv. 2021;28:408-21.

19. Xiong H, Yu Q, Gong Y, Chen W, Tong Y, Wang Y, Xu H, Shi Y. Yes-associated protein (YAP) promotes tumorigenesis in melanoma cells through stimulation of low-density lipoprotein receptor-related protein 1 (LRP1) Sci Rep. 2017;7:1-3.

20. Zhang B, Sun X, Mei H, Wang Y, Liao Z, Chen J, Zhang Q, Hu Y, Pang Z, Jiang X. LDLR-mediated peptide-22-conjugated nanoparticles for dualtargeting therapy of brain glioma. Biomaterials. 2013;34:9171-82.

21. Baranyai Z, Kock FV, Forgács A, Guidolin N, Stefania R, Vágner A, Gianolio E, Aime S. [Gd (AAZTA)]-derivatives with n-alkyl acid side chains show improved properties for their application as MRI contrast agents. Chemistry. 2020;27:1849-59.

22. Geninatti Crich S, Lanzardo S, Alberti D, Belfiore S, Ciampa A, Giovenzana GB, Lovazzano C, Pagliarin R, Aime S. Magnetic resonance imaging detection of tumor cells by targeting low-density lipoprotein receptors with Gd-loaded low-density lipoprotein particles. Neoplasia. 2007;9:1046-56.

23. Shiftan L, Israely T, Cohen M, Frydman V, Dafni H, Stern R, Neeman M. Magnetic resonance imaging visualization of hyaluronidase in ovarian carcinoma. Can Res. 2005;65:10316-23.
24. Zhao D, Wu J, Li C, Zhang H, Li Z, Luan Y. Precise ratiometric loading of PTX and DOX based on redox-sensitive mixed micelles for cancer therapy. Colloids Surf B. 2017;155:51-60.

25. Fei T, Yang $L J, M o X H$, Wang $X L$, Jun G. Metronomic paclitaxel-loaded mPEG-PLA nanoparticles show enhanced anti-tumor efficacy compared to maximum tolerated dose administration. J Nanopart Res. 2014;16:1-6.

26. Kadioglu O, Saeed ME, Mahmoud N, Azawi SS, Rincic M, Liehr T, Efferth T. Identification of metastasis-related genes by genomic and transcriptomic studies in murine melanoma. Life Sci. 2021;267:118922.

27. Writh M, Centelles M, Gedroyc W, Thanou M. Image guided focused ultrasound as a new method of targeted drug delivery. In: Thanou M, editor. Theranostic and image drug delivery. Royal Society of Chemistry; 2018. p. $1-23$.

28. Laurent S, Elst LV, Muller RN. Comparative study of the physicochemical properties of six clinical low molecular weight gadolinium contrast agents. Contrast Media Mol Imaging. 2006;1:128-37.

29. Shuvaev $S$, Akam E, Caravan P. Molecular MR contrast agents. Invest Radiol. 2021;56:20-34.

30. Aime S, Calabi L, Cavallotti C, Gianolio E, Giovenzana GB, Losi P, Maiocchi A, Palmisano G, Sisti M. [Gd-AAZTA]-: a new structural entry for an improved generation of MRI contrast agents. Inorg Chem. 2004;43:7588-90.

31. Kock FV, Forgács A, Guidolin N, Stefania R, Vágner A, Gianolio E, Aime S, Baranyai Z. [Gd (AAZTA)] - derivatives with n-alkyl acid side chains show improved properties for their application as MRI contrast agents. Chem A Eur J. 2021;27:1849-59.

32. Quattrocchi CC, Mallio CA, Errante Y. High T1 signal intensity in dentate nucleus after multiple injections of linear gadolinium chelates. Radiology. 2015:276:616-7.

33. Di Gregorio E, Ferrauto G, Furlan C, Lanzardo S, Nuzzi R, Gianolio E, Aime S. The issue of gadolinium retained in tissues: insights on the role of metal complex stability by comparing metal uptake in murine tissues upon the concomitant administration of lanthanum-and gadoliniumdiethylentriamminopentaacetate. Invest Radiol. 2018;53:167-72.

\section{Publisher's Note}

Springer Nature remains neutral with regard to jurisdictional claims in published maps and institutional affiliations.
Ready to submit your research? Choose BMC and benefit from:

- fast, convenient online submission

- thorough peer review by experienced researchers in your field

- rapid publication on acceptance

- support for research data, including large and complex data types

- gold Open Access which fosters wider collaboration and increased citations

- maximum visibility for your research: over $100 \mathrm{M}$ website views per year

At BMC, research is always in progress.

Learn more biomedcentral.com/submissions 